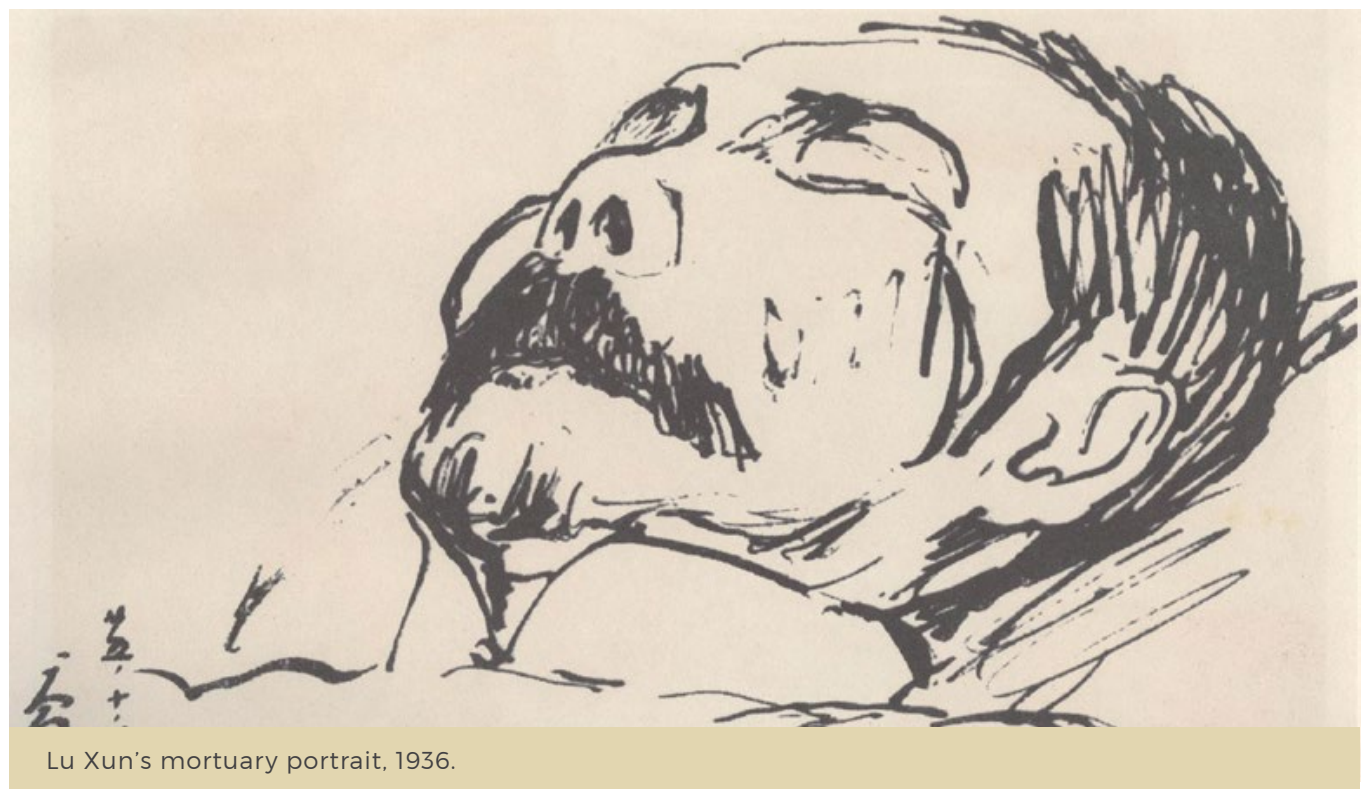

\section{Resurrecting the Dead}

\section{Ivan Franceschini}

Lu Xun today lives a new life in his homeland as well as abroad. However, given the vastness and unevenness of his oeuvre, not all his works receive the same attention. In particular, one collection of short stories stands out for their neglect: Old Tales Retold, a series of comic sketches based on ancient Chinese myths and legends published shortly before his death. This essay focusses on this semi-forgotten pearl and its relevance for today's readers.
The real misfortune suffered by men of letters lies not in being ignored and attacked in their lifetime, but comes after death when their words and conduct cease to exist; idlers pass themselves off as their confidantes spreading gossip and rumour every which way for the sake of selfpromotion. For the sake of making a little money, even a corpse becomes a tool by which they seek to secure fame and fortune, and it is this that is truly lamentable.

(Lu Xun 2017, 186-187, 94, translated by Theodore Huters)

On several occasions during his lifetime, Lu Xun (1881-1936) expressed concern over what would happen to his legacy after his death. As Eileen J. Cheng has noted, 'Lu Xun was acutely aware that after the death of the subject, texts representing the dead may take on lives of their own, as posthumous accounts can no longer be challenged by the deceased subject. Indeed, his writings selfconsciously deal with the ethics of narration and the limits of representation' (Cheng 2017, 433). Beyond the issue of people using his name for personal gain, Lu Xun worried that his writing would be distorted and manipulated to further factional and 
ideological battles. Sadly, his worst fears were to come true. In a eulogy written for the first anniversary of the writer's death, Mao Zedong hailed him as 'the sage of modern China' (xiandai zhongguo de shengren), on par with Confucius, 'the sage of feudal China'-an ironic fate for an intellectual who had spent his life attempting to break the ancient philosopher's hold on Chinese society (Mao 1939). This was the first of several speeches and articles in which Mao would appropriate $\mathrm{Lu}$ Xun for his political cause. That he was successful in this manipulation can be seen from the fact that after 1949, while the writer's former disciples and friends were falling victim to purges and violence, $\mathrm{Lu}$ Xun's name and oeuvre were used to justify a ny kind of foulness (Goldman 1982).

In spite of this, Lu Xun's legacy managed to survive and today the writer lives a new life in his homeland as well as abroad (Davies 2013a and 2013b). In China, over the past decade citations and photos of $\mathrm{Lu}$ Xun have appeared frequently on the Internet as Chinese netizens mobilised to denounce the latest injustice perpetrated by officials-be it the suppression of land protests, the muffling of critical voices, or the hypocrisy and abuses of the ruling class (Pan 2005; Henochowicz 2016). Images and characters from Lu Xun's work still appear in the conversations of ordinary people, from the 'iron house' (tiewu) where people are sleeping, unaware that they will soon be devoured by a fire raging outside, to the 'cannibalistic ethic' (chiren de lijiao) of Chinese society; from the scoundrel Ah Q, to the failed scholar Kong Yiji. I remember my surprise when, during a meeting at a women rights NGO in Beijing a few years ago, one activist referred to the 'bloody mantou' (xue mantou) - a trope from one of Lu Xun's most famous short stories, which has come to indicate the gullibility of common people, always ready to believe in the existence of absurd miraculous remedies for their problems-to complain about the obtuseness of those who refused to follow her advice.

Abroad, there has been a flourishing of new translations of $\mathrm{Lu}$ Xun into foreign languages (2010), with the latest-a collection of essays entitled Jottings under Lamplight (2017)-having been published only a few months ago. This has been accompanied by the appearance of several critical studies of remarkable breadth and profundity, such as Gloria Davies's Lu Xun's Revolution (2013), Eva Shan Chou's Memory, Violence, Queues (2012), and Eileen J. Cheng's Literary Remains (2013), to mention just a few. However, given the vastness and unevenness of the writer's oeuvre, not all his works receive the same attention. In particular, one collection of short stories stands out for their neglect: Old Tales Retold (gushi xinbian) (Lu Xun 2014), a series of comic sketches based on ancient Chinese myths and legends that Lu Xun published shortly before his death. It is on this semiforgotten pearl-and its relevance for today's readers-that this short essay will focus.

\section{The Old Tales Retold}

Old Tales Retold includes eight, short comic stories based on episodes drawn from Chinese classics. In them, we find divinities depicted as ordinary human beings, such as the goddess Nüwa, who creates mankind out of sheer boredom only to get annoyed with her creation immediately thereafter. Legendary heroes face ordinary challenges, such as an aged Hou Yi, a mythical archer who had saved the world, who has to deal with a disgruntled wife and a backstabbing disciple; or $\mathrm{Yu}$, the legendary tamer of the floods, who is confronted with the jeers of incompetent scholars and corrupt officials. Some figures come straight out of the historical annals, such as Bo Yi and Shuqi, two elders who met a tragic end because of their stubborn observance of 
Confucian morality. Others are the stuff of legends, such as Mei Jianchi, a young boy who resorts to black magic to avenge his dead father. Obviously, there is no lack of philosophers. Laozi, Mozi, and Zhuangzi appear as main characters in three of the tales. Confucius features only in an ancillary role-an absence that is far from surprising if we consider what $\mathrm{Lu}$ Xun wrote in 1926 in the afterword to his collection of essays Graves: 'As for my thinking, I have often been poisoned by Zhuangzi and Hanfeizi, at times quite casually and at others quite vigorously. I read the Confucian books earliest and most thoroughly, but they for some reason seem to have little connection with me' (Lu Xun 2017, 34, translation by Theodore Huters).

Since their publication in January 1936, Old Tales Retold never enjoyed particular renown among critics. Many were puzzled by a work so far from the realism of the writer's earlier fiction. In his preface, $\mathrm{Lu}$ Xun himself expressed scepticism about the literary value of this oeuvre: 'Most of these tales have been written in a rush, and fall short of the name 'story' as defined by literary criticism.... Moreover, having less respect for the ancients than for contemporaries, on occasions I could not avoid facetiousness' (Lu Xun 2014, 32, translation by Ivan Franceschini). Indeed, only a few months before drafting the bulk of those stories, the writer had been involved in a polemic with Lin Yutang and other proponents on the importance of 'humour' (youmo) in literature (Rea 2015, 39), going so far as to paraphrase Kierkegaard on the dangers of writing for the sheer amusement of the public:

A theatre catches fire. The clown steps to the front of the stage to announce the fact to the audience, who think it a joke and applaud. Then the clown announces again that there is a fire, but they roar with laughter and clap more loudly than ever. No doubt the world will end amid the general applause of these laughter-loving people who take everything as a joke. (Lu Xun 2003, 346-347, translated by Yang Xianyi and Gladys Yang)

While the Chinese critical debate has featured endless theoretical arguments about narrative techniques and on whether this book should be considered satire or historical fiction, discussions among the few scholars based outside China who did not dismiss this work as irrelevant have been more sanguine. In 1961, in his groundbreaking A History of Modern Chinese Fiction, C. T. Hsia described Old Tales Retold in these terms: 'In his fear of searching his own mind and disclosing thereby his pessimistic and sombre view of China at complete variance with his professed Communist faith, Lu [Xun] could only repress his deep-seated personal emotions in the service of political satire. The resulting levity and chaos... mark the sad degeneration of a distinguished if narrow talent for fiction' (1961, 46). The following year, another giant in the study of modern Chinese literature, Jaroslav Průšek, retorted: '[Lu Xun's] pictures [in Old Tales Retold] have, namely, a multiplicity of meanings, every moment relating to a number of layers of reality, their changing hues reminiscent of a winding scarf of rainbow colours. In this many-facetted iridescence lies the individuality and originality of $\mathrm{Lu}$ [Xun]'s artistic technique, which C. T. Hsia is unable to grasp...' (1962, 382). This rebuttal did not convince Hsia, however, who penned another response reiterating his opinion, citing Lu Xun's own self-deprecatory preface as evidence of the scarce value of the book (Hsia 1963).

\section{Why Read the Old Tales Retold Today?}

If even Lu Xun himself supposedly did not believe in the artistic significance of his Old Tales Retold, why rediscover this 
often overlooked book today? There are at least three reasons. First, these stories offer a glimpse into intellectual debates in Republican China that still bear relevance to China today-particularly with regard to the relationship between politics and tradition, individuals and society, and conservation and innovation. Second, by portraying ancient sages and legendary heroes not as hieratical semi-deities but as flawed human beings, Lu Xun undermines a certain kind of 'orientalist' discourse that to this day remains widespread in foreign media and academia (does this ring any Bell?). Although Ann Louise Huss (2000) hasnot without reason-associated the writer's ridicule of these figures to the physical and psychological violence against intellectuals that would be carried out during the Cultural Revolution some four decades later, the humour of Old Tales Retold undeniably provides a powerful antidote against the tendency to take the classics too seriously and to read everything related to China through pseudo-Confucian lenses. Finally, and most importantly, these tales, in their minimalism, offer a corrosive critique of any attempt at manipulating Chinese tradition for political purpose.

At its recently concluded Nineteenth Congress, the Chinese Communist Party (CCP) has amended its Constitution to include the "promotion of the creative transformation and innovative development of outstanding Chinese traditional culture' in its mission (People's Net 2017). And it is not a secret that 'Chinese traditional culture'-or at least an emasculated version of it-is at the core of the CCP's effort to promote China's soft power abroad, not least through a network of more than five hundred Confucius Institutes. In a curious assonance, in 1927, in 'The Old Tunes Are Finished', one of his most pointed essays against Chinese tradition, Lu Xun wrote of the Chinese classics as a 'soft knife' (ruan daozi), saying that the reason they are so fearsome is that readers are not alert to their danger, as they see them as being harmless (Lu Xun 2017, 173-174). Towards the end of his life, in an essay entitled 'Confucius in Modern China' published in 1935, he further elaborated on why he felt the need to attack the ancient philosopher in his writings:

Revulsion for the monk leads to distaste for the habit, and the exploitation of Confucius as an instrument to gain a certain end becoming once more transparently obvious, the desire to dethrone him grew the more potent. Therefore, when Confucius is dressed in perfect dignity, articles and works exposing his flaws are bound to appear. Confucius though he be, he must have his flaws. In normal times no one would pay them any heed, because a sage is still a man, and as such they may be forgiven him. Yet if the disciples of the Sage come forth and start prating, telling us that the Sage was this and was that, and therefore you must be likewise, people will not be able to keep from laughing out loud. (Lu Xun 2017, 186187, translation by David Pollard)

In times like these, when Chinese tradition is once again resurrected to serve dubious political purposes, it is more important than ever to rediscover the irony and sarcasm of Old Tales Retold. This is necessary not only to remind ourselves to maintain an approach to Chinese tradition devoid of dogmatism, but also to undermine the hegemonic effort of the propaganda of the CCP and the shallow authoritativeness of today's orientalists. While it is impossible to know whether by doing so we are betraying $\mathrm{Lu}$ Xun's intentions, there is a good chance that he would not have minded this opportunity 'to make the ancients out as more dead than they already are'. 
This text is taken from Gilded Age: A Year of Chinese Labour, Civil Society, and Rights, Made in China Yearbook 2017, edited by Ivan Franceschini and Nicholas Loubere, published 2018 by ANU Press, The Australian National University, Canberra, Australia.

doi.org/10.22459/MIC.04.2018.43 